\title{
Changes in Televisit Modalities Due to the Covid-Pandemic in Chile: A Comparison of Patient Satisfaction.
}

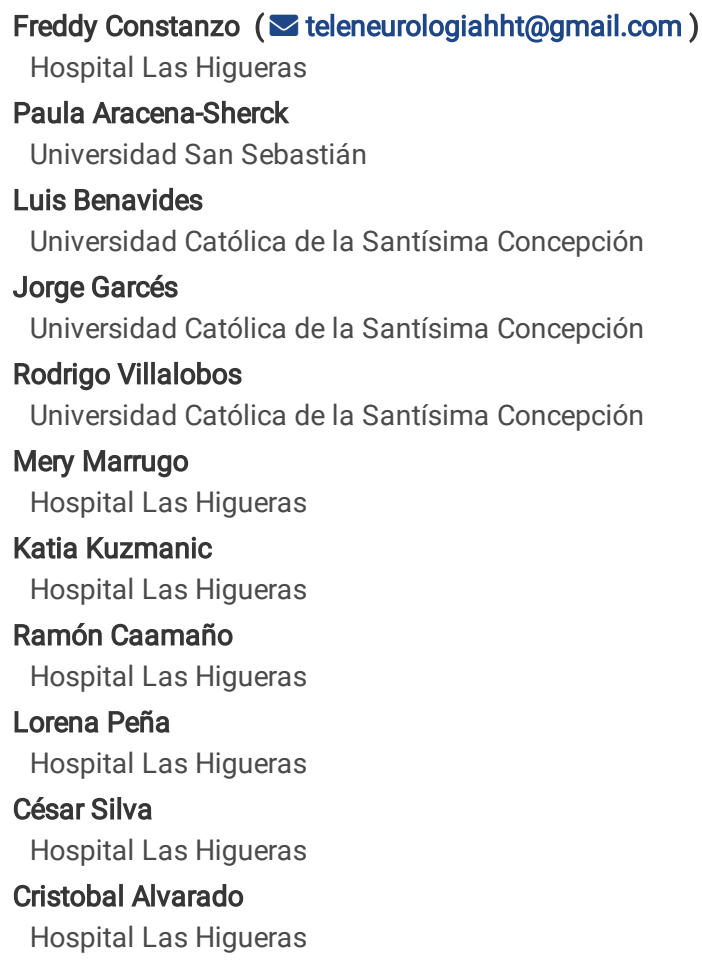




\section{Abstract}

BACKROUND: The corona virus 2019 (COVID-19) pandemic has impacted healthcare guidelines and modalities of patient consultation worldwide. The frequent cycles of quarantine confinement in Chile has caused mobility restrictions for both patients and physicians, which forced the Hospital Las Higueras de Talcahuano $(\mathrm{HHT})$ to replace the assisted televisit modality with a more classic televisit program. This change may have impacted the satisfaction of patients.

METHODS: Patient's perception of satisfaction was evaluated through self-administered survey questionnaires, previously validated in the Spanish language. Cohorts were grouped according to two relational models:i) Assisted televisit, 503 neurology patients during the years 2018-2019; and ii) Televisit, 831 patients from different specialtiestreated during 2020. Perception of satisfaction was compared by gender, age, and type of televisit, and internal consistency (Cronbach alpha) and reliability (factorial analysis of main components) were assessed.

RESULTS: Assisted televisit and televisit cohortswere composed by $64.2 \%$ and $67.6 \%$ women, respectively; patients under 65 years of age were $62.2 \%$ and $75 \%$, respectively. Assisted televisit patients showed very high $94.4 \%(n=475)$ and high $5.2 \%(n=26)$ satisfaction levels, while televisit patients showed very high $22.3 \%(n=185)$, high $63.9 \%(n=531)$, and moderate $13.1 \%(n=109)$ satisfaction levels; this difference is statistically significant at $p<0.001$. Questionnaires showed excellent internal consistency, and all items showed point biserial correlations greater than 0.30.

CONCLUSION: Lower perception of satisfaction due to the change in televisit relational modality underscores the importance of primary care professionals, who support the specialist inthe assisted televisit model. The results of this study suggest that assisted televisit contributes to delivering an integrative solution that helps to alleviate the fragmentation of the system.

\section{Introduction}

Chile is a country located in the extreme south of the American continent, with a population of $19,678,363$ inhabitants, according to the latest census data (1). As with any other country in the planet, the coronavirus 2019 (COVID-19) pandemic has impacted healthcare guidelines and modalities of patient consultation, in order to face the challenges of different degrees of confinement during quarantine periods (2-4). Currently, the country ranks fairly high in worldwide COVID-19 related morbidity (15th, with 1,051,270 total cases) (5) and mortality (32nd, with 1,249 death cases per million inhabitants) (2). Due to COVID-19 pandemic, the Chilean healthcare system has increased the number of intensive care units (ICU) bed from 1550 (April 14th 2020), with an occupancy rate of about $64 \%$, to 4484 (June 29th 2021) ICU beds with an occupancy rate of about $94 \%$ (6). In addition, massive admittance of patients with COVID-19 symptoms has adversely impacted outpatient treatment, leading to a decrease in the number of in situ consultation hours for outpatients with non-COVID-19 diseases. Prior to the COVID-19 pandemic, the waiting list for the first specialty consultation at December 31th, 2019 was 1,653,555 patients (7), and at March 31th, 2021 the waiting list for the first specialty consultation was 1,932,422 patients (8) with an increase in the waiting list of first consultation of $16 \%$.

The Chilean healthcare system is organized in hospitals, tertiary facilities housing both inpatient programs and specialist physician outpatient consultations, and primary or secondary care facilities, where general practitioners manage most of non-specialty related outpatient consultations. There is a close interfacility relationship allowing the timely transfer of a patient from the primary/secondary care facility to the hospital, for either an outpatient consultation with a specialist physician or for his or her admittance as inpatient $(9,10)$. The multiple changes to quarantine confinement implemented throughout the COVID-19 pandemic have hindered patient and physician mobility, and thus, the flow of patients between the different levels of healthcare facilities. The Hospital Las Higueras de Talcahuano (HHT), a facility dependent of the Servicio de Salud de Talcahuano (SST, Ministry of Health), and located in the south of the country, is not strange to this reality. Among the several measures needed to overcome the limited bed availability and decreased time for outpatient consultation, televisit emerges as an opportunity to remotely treat outpatients, not only reducing the burden of the HHT personnel but also the likelihood of COVID-19 contagion for the patients. Therefore, the HHT has modified its outpatient programs to implement televisit for all health specialties.

Televisits can be implemented through several modalities, each of them with pros and cons in terms of the relationship between the patient and the remote physician. In the HHT, two televisit models have been implemented, both of them coordinated by the Teleprocess Unit (TPU) at HHT: 1) a televisit modality (Fig. 1A), in which patients connect to the remote specialist on their own (usually from their homes), and 2) an assisted televisit modality (Fig. 1B), in which patients connect, at the primary/secondary care facility or from their home, to the remote specialist physician, in the presence of a general practitioner acting as an in situ assistant to the specialist. The SST has pioneered the latter model in Chile, with a teleneurology program implemented in March 2015, allowing management of adult neurological patients waiting for their first consultation (10). This assisted televisit program runs in a synchronous mode, with the outpatient consulting with a general practitioner in the primary/secondary care facility (Fig. 1B); the latter professional has been specifically trained for this purpose and helps connecting the outpatient with a neurologist at the HHT via HDTV videoconference (9). The HHT teleneurology program has successfully allowed the remote care of outpatients at local primary and secondary facilities and has been shown to improve access to medical care by neurologist specialists, by exhibiting a high level of user satisfaction (9), while decreasing the waiting time for a first consultation and providing timely follow-up appointments in different neurologic diseases $(10,11)$

Although the assisted televisit model has been successful in the HHT, this modality relies on patient mobility to secondary and tertiary healthcare facilities, which has been hindered by frequent cycles of different degrees of quarantine confinement due to the COVID-19 pandemic. Therefore, the HHT has been forced to move away from the assisted televisit modality in favor of a more classic televisit program, to overcome both outpatient and physician quarantine-derived mobility restrictions $(12,13)$. In the latter modality (see Fig. $1 \mathrm{~A}$ ), the medical specialist contacts patients directly from the HHT through 
an electronic device such as smartphone or computer (usually at their home). The televisit modality has been previously shown to be successful in highly developed regions (14); this modality, however, appears to be less accepted by communities in underdeveloped or developing regions (15, 16). Although most likely multifactorial, causes for community acceptance of the televisit or assisted televisit modalities have yet to be elucidated. The modality change in the HHT teleneurology program, from an assisted televisit consultation to a televisit one during the COVID-19 pandemic, provides an opportunity to evaluate potential differences in patient satisfaction between these two televisit modalities. The present study shows results of a patient satisfaction survey, previously validated for the HHT teleneurology program (9), with outpatients from different medical specialties, that consulted through the televisit modality in 2020, and their comparison with the assisted televisit modality implemented in 2019 (9). Data are discussed in the context of factors allowing populations to prefer one or another modality in televisit.

\section{Methods}

Telemedicine care modalities: Here we define two relational models, i) Assisted televisit and ii) televisit. Assisted televisit is a relational model already published by Contanzo et al. (9): it consists of the connection of the specialist doctor who is located in the hospital with the patient who is located in a local primary health service, both assisted by the TPU (Fig. 1A). The patient in this modality is accompanied by a general medical practitioner who works in the local primary care service. The second model, televisit, was implemented in the HHT by the TPU, due to the COVID-19 pandemic-derived confinement of patients in their homes. In this model, the specialist contacts the patient directly through electronic devices without the assistance of another health professional from the primary care service (Fig. 1B).

Patient Cohorts: Patient cohorts were divided according to the televisit model: i) Assisted televisit, corresponding to a cross-sectional study of 503 patients of the HHT Teleneurology program, treated in the assisted televisit modality during the years 2018-2019; and ii) Televisit, corresponding to a crosssectional study of a cohort of 831 patients treated during 2020 in the HHT Telemedicine program (assisted by the TPU) from different medical specialties: Bronchopulmonary, Cardiosurgical, Cardiology, Endocrinology, Gastroenterology, Geriatric, Hematology, Internal Medicine, Physical medicine, Nephrology, Neurology, Oncology, Otorhinolaryngology, Rheumatology, and Others.

Inclusion Criteria: Participants of the Assisted televisit cohort had to meet the inclusion criteria described in Constanzo et al (9). Participants of the Televisit cohort had to meet the following inclusion criteria: i) to consent for remote care, included new appointments and controls; ii) to have internet connection and at least a computer, a tablet, or a smartphone with camera; iii) to present a pathology not requiring emergency care and are stable; iv) to be of legal age and mentally competent, according to the Chilean Law (Bill 28584, article 28). The research protocol was approved by the Scientific Ethics Committee of the SST of the Ministry of Health. All participants signed a written informed consent.

Survey design assisted televisit and televisit: To evaluate the patient's perception of satisfaction, two essentially identical surveys were employed. The assisted televisit survey evaluated patient perception of satisfaction using the questionnaire designed and constructed in Spanish, consisting of a total of 23 questions with closed responses on a single Likert scale (totally disagree, disagree, neither agree nor disagree, agree, totally agree), which was previously validated by Constanzo et al (9). The survey questionnaire, with a maximum score of 115 points, was graded in terms of satisfaction: very low (under or equal to 23 points), low (24 to 46 points), moderate (47 to 69 points), high (70 to 92 points), and very high ( 93 to 115 points). The televisit survey was identical to the previous one, except for the exclusion of questions related to the general medical practitioner from the primary health center (questions $13,17,22$ and 23), as this professional is absent from this model. Following this adaptation, the survey consisted in a total of 19 questions with closed responses on a single Likert scale (totally disagree, disagree, neither agree nor disagree, agree, totally agree). The survey questionnaire, with a maximum score of 95 points, was graded in terms of satisfaction: very low (under or equal to 19 points), low (20 to 38 points), moderate (39 to 57 points), high (58 to 76 points), and very high (77 to 95 points). Both questionnaires were self-administered to safeguard the anonymity of the study participant.

Survey evaluation and statistical analysis. A descriptive analysis of normality of the sample (Kolmogorov-Smirnov) was conducted. The internal consistency was evaluated by Cronbach's alpha test, which suggests the following scale for alpha coefficients: excellent (>0.9), good (>0.8), acceptable (> $0.7)$, questionable $(>0.6)$, poor $(>0.5)$, and unacceptable $(<0.5)(9)$. Difficulty and discrimination of the instrument were evaluated by index of difficulty and specific biserial correlation, respectively. To compare the means of both surveys with a not normal distribution, we used The Mann-Whitley $U$ test for independent samples. All analyses were carried out in SPSS, version 25.0. Statistical significance was established at $p<0.05$.

Ethics approval and consent to participate: This project was approved by Scientific Ethics Committee of the SST of the Ministry of Health (Acta $\mathrm{N}^{\circ} 97$ from 12.12.2017). I confirm that all research was performed in accordance with relevant guidelines/regulations, and theinformed consent was obtained from all participants and/or their legal guardians. Consent obtained from study participants was written (assisted televisit)and verbal (televisit) and both ways were approved by the ethics committee. 
Table 1

Patients of assisted televisit $(n=503)$ and televisit $(n=803)$ modality categorized by gender and age.

\begin{tabular}{|lllll|}
\hline \multicolumn{4}{|l|}{ Assisted Televisit } & \multicolumn{2}{l|}{ Televisit } \\
\hline GENDER & $\mathbf{n}$ & $\%$ & $\mathbf{n}$ & $\%$ \\
\hline Male & 180 & 35,8 & 269 & 32,4 \\
Female & 323 & 64,2 & 562 & 67,6 \\
\hline Total & 503 & 100,0 & 831 & 100,0 \\
\hline AGE & $\mathbf{n}$ & $\%$ & $\mathbf{n}$ & $\%$ \\
\hline Under 65 & 313 & 62,2 & 623 & 75,0 \\
\hline Over 65 & 190 & 37,8 & 208 & 25,0 \\
\hline Total & 503 & 100,0 & 831 & 100,0 \\
\hline
\end{tabular}

Table 2

Televisit patients categorized by medical specialty $(n=831)$. All patients of assisted televisit were neurology patients.

\begin{tabular}{|lll|}
\hline Medical Specialty & Frequency & Percentage \\
\hline Endocrinology & 165 & $20 \%$ \\
\hline Otorhinolaryngology & 126 & $15 \%$ \\
\hline Bronchopulmonary & 122 & $15 \%$ \\
\hline Internal Medicine & 91 & $11 \%$ \\
\hline Neurology & 68 & $8 \%$ \\
\hline Gastroenterology & 56 & $7 \%$ \\
\hline Cardiology & 46 & $6 \%$ \\
\hline Hematology & 39 & $5 \%$ \\
\hline Cardiosurgery & 26 & $3 \%$ \\
\hline Others & 23 & $3 \%$ \\
\hline Rheumatology & 21 & $3 \%$ \\
\hline Physical Medicine \& Rehabilitation & 19 & $2 \%$ \\
\hline Geriatrics & 11 & $1 \%$ \\
\hline Oncology & 10 & $1 \%$ \\
\hline Nephrology & 8 & $1 \%$ \\
\hline Total & 831 & $100 \%$ \\
\hline
\end{tabular}

Table 3

User satisfaction of assisted televisit $(n=503)$.

\begin{tabular}{|lll|}
\hline Variables & \multicolumn{2}{l|}{ Total } \\
\cline { 2 - 3 } & $\mathbf{n}$ & $\%$ \\
\hline User Satisfaction & & \\
\hline Very low satisfaction ( $\leq 23$ points on satisfaction scale) & - & - \\
\hline Low satisfaction (24-46 points on satisfaction scale) & - & - \\
\hline Moderate satisfaction (47-69 points on satisfaction scale) & 2 & $0,4 \%$ \\
\hline High satisfaction (70-92 points on satisfaction scale) & 26 & $5,2 \%$ \\
\hline Very high satisfaction (93-115 points on satisfaction scale) & 475 & $94,4 \%$ \\
\hline Total & 503 & $100 \%$ \\
\hline
\end{tabular}

Page $4 / 13$ 


\begin{tabular}{|c|c|c|}
\hline \multirow[t]{2}{*}{ Variables } & \multicolumn{2}{|c|}{ Total } \\
\hline & $\mathbf{n}$ & $\%$ \\
\hline \multicolumn{3}{|l|}{ User satisfaction } \\
\hline Very low satisfaction ( $\leq 19$ points on satisfaction scale) & 1 & $0,1 \%$ \\
\hline Low satisfaction (20-38 points on satisfaction scale) & 5 & $0,6 \%$ \\
\hline Moderate satisfaction (39-57 points on satisfaction scale) & 109 & $13,1 \%$ \\
\hline High satisfaction (58-76 points on satisfaction scale) & 531 & $63,9 \%$ \\
\hline Very high satisfaction (77-95 points on satisfaction scale) & 185 & $22,3 \%$ \\
\hline Total & 831 & $100 \%$ \\
\hline
\end{tabular}

Table 5. Descriptive data of the total population by mean per question, difficulty, mean when the question is deleted, reliability analysis (a-Cronbach), and biserial correlation of the patient satisfaction survey, used in assisted televisit $(n=503)$ and televisit (831). 


\begin{tabular}{|c|c|c|c|c|c|c|c|c|c|c|c|}
\hline \multirow[b]{2}{*}{$\mathbf{N}^{\circ}$} & \multirow[b]{2}{*}{ Variables } & \multicolumn{5}{|c|}{ Assisted Televisit $(n=503)$} & \multicolumn{5}{|c|}{ Televisit $(n=831)$} \\
\hline & & $\begin{array}{l}\text { Mean } \\
\text { per } \\
\text { question }\end{array}$ & Difficulty & $\begin{array}{l}\text { Biserial } \\
\text { Correlation }\end{array}$ & $\begin{array}{l}\text { Mean } \\
\text { when } \\
\text { the } \\
\text { question } \\
\text { is } \\
\text { deleted }\end{array}$ & $\begin{array}{l}\text { a when } \\
\text { the } \\
\text { question } \\
\text { is } \\
\text { deleted }\end{array}$ & $\begin{array}{l}\text { Mean } \\
\text { per } \\
\text { question }\end{array}$ & Difficulty & $\begin{array}{l}\text { Biserial } \\
\text { Correlation }\end{array}$ & $\begin{array}{l}\text { Mean } \\
\text { when } \\
\text { the } \\
\text { question } \\
\text { is } \\
\text { deleted }\end{array}$ & $\begin{array}{l}\text { a when } \\
\text { the } \\
\text { question } \\
\text { is } \\
\text { deleted }\end{array}$ \\
\hline & & & & & & 0,90 & & & & & 0,94 \\
\hline 1 & $\begin{array}{l}\text { I am satisfied } \\
\text { with the care } \\
\text { received in } \\
\text { Telemedicine. }\end{array}$ & 4,83 & 0,97 & 0,63 & 104,22 & 0,90 & 4,47 & 0,89 & 0,70 & 77,39 & 0,93 \\
\hline 2 & $\begin{array}{l}\text { My family is } \\
\text { satisfied with the } \\
\text { care received in } \\
\text { Telemedicine. }\end{array}$ & 4,44 & 0,89 & 0,40 & 104,62 & 0,90 & 4,28 & 0,86 & 0,66 & 77,57 & 0,93 \\
\hline 3 & $\begin{array}{l}\text { Telemedicine } \\
\text { helps me to know } \\
\text { my state of } \\
\text { health. }\end{array}$ & 4,75 & 0,95 & 0,54 & 104,30 & 0,90 & 4,16 & 0,83 & 0,71 & 77,70 & 0,93 \\
\hline 4 & $\begin{array}{l}\text { Telemedicine } \\
\text { helps me know } \\
\text { how to improve } \\
\text { my health status. }\end{array}$ & 4,71 & 0,94 & 0,55 & 104,34 & 0,90 & 4,18 & 0,84 & 0,69 & 77,67 & 0,93 \\
\hline 5 & $\begin{array}{l}\text { Telemedicine } \\
\text { allows me to } \\
\text { better follow the } \\
\text { recommendations } \\
\text { and indications of } \\
\text { my specialist } \\
\text { doctor. }\end{array}$ & 4,79 & 0,96 & 0,58 & 104,27 & 0,90 & 4,28 & 0,86 & 0,70 & 77,57 & 0,93 \\
\hline 6 & $\begin{array}{l}\text { I felt comfortable } \\
\text { talking to my } \\
\text { specialist doctor } \\
\text { through a camera } \\
\text { and a } \\
\text { microphone. }\end{array}$ & 4,71 & 0,94 & 0,54 & 104,34 & 0,90 & 4,49 & 0,90 & 0,68 & 77,36 & 0,93 \\
\hline 7 & $\begin{array}{l}\text { Talking to my } \\
\text { specialist doctor. } \\
\text { through a camera } \\
\text { and a } \\
\text { microphone. was } \\
\text { as effective as in } \\
\text { person. }\end{array}$ & 4,58 & 0,92 & 0,69 & 104,48 & 0,89 & 3,89 & 0,78 & 0,74 & 77,97 & 0,93 \\
\hline 8 & $\begin{array}{l}\text { During my } \\
\text { Telemedicine care } \\
\text { it was easy for } \\
\text { me to explain my } \\
\text { health problem to } \\
\text { my specialist } \\
\text { doctor. }\end{array}$ & 4,67 & 0,93 & 0,61 & 104,38 & 0,90 & 4,40 & 0,88 & 0,71 & 77,45 & 0,93 \\
\hline 9 & $\begin{array}{l}\text { My specialist } \\
\text { doctor has } \\
\text { identified my } \\
\text { health problem } \\
\text { through } \\
\text { Telemedicine. }\end{array}$ & 4,70 & 0,94 & 0,53 & 104,36 & 0,90 & 4,22 & 0,84 & 0,67 & 77,64 & 0,93 \\
\hline 10 & $\begin{array}{l}\text { I have been } \\
\text { informed of my } \\
\text { right to privacy of } \\
\text { my personal and } \\
\text { medical } \\
\text { information } \\
\text { included in } \\
\text { Telemedicine. }\end{array}$ & 4,68 & 0,94 & 0,22 & 104,37 & 0,91 & 4,05 & 0,81 & 0,38 & 77,80 & 0,94 \\
\hline 11 & $\begin{array}{l}\text { I trust that my } \\
\text { personal } \\
\text { information and } \\
\text { privacy will be } \\
\text { protected after } \\
\text { my attention by } \\
\text { Telemedicine. }\end{array}$ & 4,81 & 0,96 & 0,54 & 104,24 & 0,90 & 4,39 & 0,88 & 0,62 & 77,47 & 0,93 \\
\hline 12 & The quality of the & 4,76 & 0,95 & 0,36 & 104,30 & 0,90 & 4,50 & 0,90 & 0,58 & 77,35 & 0,93 \\
\hline
\end{tabular}


image and sound

were adequate to

talk to my

specialist doctor.

\begin{tabular}{|c|c|c|c|c|c|c|c|c|c|c|c|}
\hline $13^{*}$ & $\begin{array}{l}\text { The general } \\
\text { doctor who } \\
\text { accompanied me } \\
\text { in person helped } \\
\text { me during my } \\
\text { Telemedicine } \\
\text { consultation. * }\end{array}$ & 4,88 & 0,98 & 0,50 & 104,17 & 0,90 & & & & & \\
\hline 14 & $\begin{array}{l}\text { My attention by } \\
\text { Telemedicine was } \\
\text { helpful to me. }\end{array}$ & 4,84 & 0,97 & 0,74 & 104,21 & 0,89 & 4,45 & 0,89 & 0,82 & 77,41 & 0,93 \\
\hline 15 & $\begin{array}{l}\text { The time with a } \\
\text { specialist is faster } \\
\text { by Telemedicine. }\end{array}$ & 4,74 & 0,95 & 0,49 & 104,31 & 0,90 & 4,21 & 0,84 & 0,54 & 77,65 & 0,94 \\
\hline 16 & $\begin{array}{l}\text { I prefer } \\
\text { Telemedicine } \\
\text { because it is } \\
\text { easier to go to the } \\
\text { doctor's office } \\
\text { than to go to the } \\
\text { hospital. }\end{array}$ & 4,71 & 0,94 & 0,61 & 104,34 & 0,90 & 4,25 & 0,85 & 0,57 & 77,60 & 0,93 \\
\hline $17 *$ & $\begin{array}{l}\text { I prefer } \\
\text { Telemedicine } \\
\text { because it is } \\
\text { cheaper to go to } \\
\text { the office than to } \\
\text { go to the hospital. }\end{array}$ & 4,56 & 0,91 & 0,49 & 104,50 & 0,90 & & & & & \\
\hline 18 & $\begin{array}{l}\text { For my future } \\
\text { controls I will } \\
\text { prefer to continue } \\
\text { using } \\
\text { Telemedicine. }\end{array}$ & 4,56 & 0,91 & 0,49 & 104,50 & 0,90 & 3,95 & 0,79 & 0,60 & 77,90 & 0,93 \\
\hline 19 & $\begin{array}{l}\text { My specialist } \\
\text { doctor was able } \\
\text { to answer my } \\
\text { questions through } \\
\text { Telemedicine }\end{array}$ & 4,87 & 0,97 & 0,63 & 104,19 & 0,90 & 4,53 & 0,91 & 0,71 & 77,33 & 0,93 \\
\hline 20 & $\begin{array}{l}\text { My specialist } \\
\text { doctor showed } \\
\text { concern in solving } \\
\text { my health } \\
\text { problem during } \\
\text { Telemedicine } \\
\text { care. }\end{array}$ & 4,84 & 0,97 & 0,52 & 104,21 & 0,90 & 4,57 & 0,91 & 0,70 & 77,29 & 0,93 \\
\hline 21 & $\begin{array}{l}\text { I trust the } \\
\text { instructions of my } \\
\text { specialist doctor } \\
\text { during my } \\
\text { Telemedicine } \\
\text { care. }\end{array}$ & 4,87 & 0,97 & 0,66 & 104,18 & 0,90 & 4,60 & 0,92 & 0,72 & 77,25 & 0,93 \\
\hline $22^{*}$ & $\begin{array}{l}\text { The general } \\
\text { practitioner who } \\
\text { accompanied me } \\
\text { in person during } \\
\text { the Telemedicine } \\
\text { service was able } \\
\text { to answer my } \\
\text { questions.* }\end{array}$ & 4,86 & 0,97 & 0,55 & 104,19 & 0,90 & & & & & \\
\hline $23^{*}$ & $\begin{array}{l}\text { The general } \\
\text { practitioner who } \\
\text { accompanied me } \\
\text { in person during } \\
\text { the Telemedicine } \\
\text { care could answer } \\
\text { the questions of } \\
\text { my specialist } \\
\text { doctor. * }\end{array}$ & 4,89 & 0,98 & 0,54 & 104,16 & 0,90 & & & & & \\
\hline
\end{tabular}

\section{Results}


Patient cohort description assisted televisit and televisit: The Assisted televisit cohort consisted of $64.2 \%$ women and $35.8 \%$ men; $62,2 \%$ of patients were under 65 years old, and $37.8 \%$ were older. On the other hand, the Televisit cohort consisted of $67.6 \%$ women and $32.4 \%$ men; $75 \%$ of patients were under 65 years old, and $25 \%$ were older (Table 1 ).

While allparticipants of the Assisted televisit cohort were neurological patients, those of theTelevisit cohortconsulted different medical specialties: Endocrinology 20\% ( $n=165)$, Otorhinolaryngology 15\% ( $n=126)$,Bronchopulmonary 15\% ( $n=122)$,Internal Medicine 11\% ( $n=91)$,Neurology $8 \%$ $(n=68)$, Gastroenterology $7 \%(n=56)$,Cardiology 6\% $(n=46)$,Hematology 5\% ( $n=39)$,Cardiosurgery 3\% ( $n=26), 0$ thers $3 \%(n=23)$, Rheumatology 3\% ( $n=21)$,Physical Medicine \& Rehabilitation 2\% ( $n=19)$, Geriatrics 1\% ( $=11)$,Oncology 1\% ( $=10)$, and Nephrology $1 \%(n=8)($ Table 2$)$.

In terms of the perception of satisfaction with each model,different patterns of satisfaction arose: Assisted televisit patients showed very high $94.4 \%$ $(n=475)$ and high $5.2 \%(n=26)$ satisfaction (Table 3), whileTelevisit patients showed very high $22.3 \%(n=185)$, high $63.9 \%(n=531)$ and moderate $13.1 \%$ $(n=109)$ satisfaction (Table 4). Comparison of participant satisfaction in both cohorts by gender andage did not result in significant differences ( $p<0.05$, Kolmogorov Smirnov's $p<0.05$ ) (data not shown). To performa proper comparison of satisfaction perception the two cohorts, we did not consider the questions 13, 17, 22 and 23 from the Assisted televisit questionnaire. Assisted televisit and Televisit cohorts showed mean satisfactions of $89,86 \% \pm 6.85$ and $81.85 \% \pm 11.61$, respectively ( $p<0.001$, Kolmogorov Smirnov's $p<0.05)$, (Figure 2 ).

Survey evaluation: The reliability analysis of the questionnaire (Table 5) showed that internal consistency was high, with a Cronbach's alpha of 0.90 and 0.94 for assisted televisit and televisit, respectively. Every item showed Cronbach's alphas values around 0.9 . Means of patient satisfaction scoreswere $104.4 \pm 0.12$ points and $77.55 \pm 0.21$ for Assisted televisit and Televisit, respectively. The elimination of any of the questionnaire items led to maintaining its reliability as very high (Cronbach's alpha $>0.9$ ), regardless of the identity of the removed item. The difficulty of the instrument's questions was assessed by using the difficulty index. Noteworthy, none of the items showed a difficulty index lower than 0.10 , showing. high discrimination indexes (Table 5 ).

\section{Discussion}

Televisit arises as an attractive tool to address some of the deficits in the timely access to healthcare for patients from different settings. In Chile, the HHT has pioneered the implementation of a Teleneurology program since 2015 , with the ambitious goal of increasing access of adult patients,throughremote neurological consultation. Since its inception, the TPU at HHT has employedthe assisted televisitmodel.The COVID-19 pandemic, however, forced the switch to a televisit modelin theNeurology Unit, and the further widening to other medical specialties, whichdid not previouslyhave a telemedicine model previously.

Telemedicine is currently capable of providing health care to new and controls patients, from a huge geographical area, contributing to the continuity of care $(17,18)$ and to the operational principle of system sufficiency and minimum social security benefits (19). In fact, after the model switch, the TPU started with 3 specialties(Cardiology, Heart surgery and Neurology) and currently handles 15 different medical specialties. Moreover, Endocrinology, Otorhinolaryngology and Bronchopulmonary seamlesslyadopted the televisitmodel, which now covers $50 \%$ of their entirepatient population.

In the present study, wecomparedthe patient's perception of satisfaction between assisted televisit and televisit models for the first time in Chile.Statistical analyses of data resulting from this study showed high reliability and internal consistency of the designed questionnaires. In addition to the previously reported data(9), biserial correlation analysis showed that all selected questionnaire items were suitable for surveys used in both patient cohorts. In agreement with our previous findings (9), the present study indicates that neither telemedicine intervention hinder the development of the link between patient and their specialists(20).In addition, with no significant differences in patients' satisfaction by gender or age.telemedicinemight be usefulin the population, regardless of age, as long as they are digitally-able.

Our analysis showed that assisted televisit displayed significantly higher satisfaction over the televisit model. This underlines the importance of the primary care professionalsto support the specialist during the televisitto achieve greater user satisfaction in the public health system, making the assisted televisit model at the HHT one of many high standards of care that itdelivers in daily basis. Although lower than the assisted televisit model, televisit still displayeda high patient satisfaction. Thus, it can be considered for exceptional situations, such us patients: i) located in remote areas with little or no access primary or secondary health services, or inaccessible for home visits,ii) in disaster areas,iii) with severe mobility limitation, iv) in overloaded health centers, or v) isolated/quarantined patients, as is the case in the current pandemic.

This study is based on data from participants grouped in cohorts by convenience sampling. On one end, participants from each cohort were recruited at different times, the Assisted Televisit during 2015-2019 and the Televisit cohort during 2020. Since the latter cohort had an additional stressor, i.e. a quarantine confinement during a very publicized pandemic, it is possible that that lower satisfaction scores maybe explained, at least in part, because of a higher psychological stress on patients rather than the actual televisit perception. On the other end, the Assisted Televisit cohort of patients belonged to only one specialty (Adult Neurology) with over 5 years' experience with telemedicine programs, while the Televisit cohort belonged to 15 different specialties that did not have prior experience in this field. Therefore, it is also possible that the difference in professional team experience with the televisit paradigm may have impacted the perception of satisfaction by their patients. Nevertheless, there is evidence suggesting that the patient's perception of satisfaction with televisit programs varies according to his or her needs (21). The consensus among specialists (22) is that there are three pillars required to achieve high levels of user satisfaction with a televisit program: i) good connectivity to achieve a good audio and video connection, ii) readily availability of electronic medical records, and iii) of a patient-centered care system (23). The present study underscores how relevant is the third of these pillars for the perception of satisfaction of the patient: the population served through assisted televisit model has greater user satisfaction than a more classical one. We propose that such greater satisfaction is likelydue to a patient's better understanding of and access to all the indications given by the specialist physician, 
through reinforcement and managing by the general practitioner who accompanies the patient in situ during the televisit. This modality allows for several advantages for the patient, including: i) the patient is better appraised of his or her diagnosis and treatment by two physicians instead of one, reinforcing the clinical messages; ii) in most cases, there is an already ongoing rapportbetween the patient and the general practitioner, which in turn, facilitates and strengthens the one of the patient with the specialist; and iii) since the general practitioner works in a healthcare institution that covers the geographical area where the patient lives in, this professional can better perceive the patient's livelihood reality,facilitating the specialist-patient dialogue. (10,11,20). Furthermore, the assisted televisit model generates a space for continuous collaboration between tertiary and primary healthcare, highlighting the importance of a team work that contributes to overcomingthe fragmentation evidenced in the Chilean health system and other latitudes, through an integrative solution that reinforces a patient-centered praxis, instead of a institutional-centered one(24).

The HHT TPU has pioneered the assisted televisit modality in the region, and the hurdles imposed by the COVID-19 pandemic has allowed for the widening of the specialty spectrum of telemedicine programs. We expect that once this pandemic is managed, the TPU not only will be able to restore assisted televisit modality but also implement this model to more specialties in the HHT. In addition, there are still several landmarks to be accomplished in this area of healthcare: i) to further widen the spectrum of specialties covered by the TPU, ii) to educate the health community and patients in remote care, and iii) to create a new digital hospital with new facilities.Overall, high satisfaction scores shown in the present study indicate that patients in both the public and private healthcare systems would be benefited by implementing telemedicine programs, in particular, under the assisted model.

\section{Abbreviations}

Hospital Las Higueras of Talcahuano (HHT)

Teleprocess Unit (TPU)

Health Service of Talcahuano (SST) of the Ministry of Health.

\section{Declarations}

Ethics approval and consent to participate. The research protocol was approved by Scientific Ethics Committee of the SST of the Ministry of Health (Acta $\mathrm{N}^{\circ} 97$ from 12.12.2017). All participants signed a written informed consent.

\section{Documento de Formulario de Información para el estudio "VALIDATION OF A PATIENT SATISFACTION SURVEY OF THE TELENEUROLOGY PROGRAMME IN CHILE"}

Este formulario de Consentimiento Informado se dirige a hombres y mujeres que son atendidos en el programa de Teleneurología del Hospital Higueras de Talcahuano, y a los que se les invita a participar en una investigación cuyo objetivo es validar un instrumento de recolección de datos que permita medir la satisfacción usuaria de los pacientes respecto de la atención neurológica recibida mediante el programa de Teleneurología del HHT.

El investigador principal de esta investigación es el Dr. Freddy Constanzo Parra, la cual se encuentra patrocinada por la Universidad Católica de la Santísima Concepción.

\section{Introducción}

Yo soy (nombre del médico tratante encargado de solicitar el consentimiento informado), trabajo para el Servicio de Salud de Talcahuano y formo parte del equipo de investigación del Dr. Constanzo. Actualmente, queremos validar una encuesta que permita conocer el nivel de satisfacción de la población con respecto a la atención recibida en el programa de Teleneurología, por lo que vengo a invitarlo a participar de esta investigación. No tiene que decidir hoy si participa o no en el estudio. Antes de decidirse, puede hablar con alguien que se sienta cómodo y en confianza sobre la investigación.

Puede que haya algunas palabras que no comprenda, por ello cuando lo estime necesario puede pararme para recibir la explicación que necesite. Si tiene alguna pregunta puede preguntarme a mí o a cualquier miembro del equipo de investigación cuando lo estime necesario.

\section{Propósito}

Validar un instrumento que permita conocer la satisfacción de los usuarios de un programa, lo cual en un futuro permitirá identificar errores y mejorar falencias, prestando así una atención de mayor calidad a los usuarios.

\section{Tipo de Intervención de Investigación}

Esta investigación sólo incluye la contestación de una encuesta, la cual será anónima y completada por usted en un ambiente de tranquilidad y respeto. En caso de no saber leer o presentar un problema que le impida completar la encuesta, personalmente me haré cargo de ayudarlo para responder, asegurándole un ambiente de seguridad y anonimato.

El tiempo para completar esta encuesta no será superior a los 30 minutos.

\section{Selección de participantes}

Estamos invitando a adultos que han formado parte del programa de Teleneurología a responder esta encuesta. 
Su participación en esta investigación es totalmente voluntaria. Usted puede elegir participar o no hacerlo. Tanto si elige participar o no, continuarán todos los servicios que recibía en este programa y nada cambiará. Usted puede cambiar de idea más tarde y dejar de participar aun cuando lo haya aceptado antes.

\section{Riesgos}

Esta investigación no implica ningún riesgo para su salud.

\section{Beneficios}

Esta investigación no implica ningún beneficio económico.

\section{Confidencialidad}

Nosotros no compartiremos la identidad de las personas que participen de esta investigación. Las respuestas que se obtengan a través de esta encuesta se mantendrán en absoluta confidencialidad.

\section{Compartiendo los Resultados}

Los hallazgos encontrados en esta investigación podrán ser utilizados para realizar publicaciones científicas, obviamente sin revelar la identidad de los participantes.

\section{A Quién Contactar}

Si tiene cualquier pregunta puede hacerla ahora o más tarde, incluso después de haber respondido la encuesta.

Si desea realizar preguntas más tarde puede contactar al Dr. Freddy Constanzo Parra, Jefe del Servicio de Neurología del Hospital las Higueras de Talcahuano. Dirección Alto Horno 777. Talcahuano. Fono: 41-2687345. Email: neurologia.higueras@redsalud.gov.cl.

También pude consultar al Comité Ético Científico del Servicio de Salud de Talcahuano, que es un comité cuya tarea es asegurarse de que se protege de daños a los participantes en la investigación. Nombre presidente de comité: Dra. Marcela Cortés, fono 41-2722150. Email: etica.sst@redsalud.gov.cl.

\section{Encuestas Online.}

Las encuestas online fueron realizadas vía telemática y todos los pacientes consintieron contestar la encuesta remota.

Consent for publication: Not applicable.

Availability of data and material. The dataset supporting the conclusions of this article is included within the article and its additional file.

Competing interests. I declare that me (Dr. Freddy Constanzo) and all the authors included in this manuscript have no conflict of interest.

Funding. Not applicable.

Authors' contributions: All authors have read and approved the manuscript

FC: Study conception and design, supervision of informed consent signing and survey application, and manuscript elaboration.

PA-S: Manuscript elaboration and English editing.

LB: Clinician and survey application.

JG: Clinician and survey application.

RV: Clinician and survey application.

MM: Clinician and survey application.

KK: Clinician and survey application.

RC: Clinician and survey application.

LP: Clinician and survey application.

CS: Supervision of Teleprocesses Unit.

CA: Statistical analysis, research coordinator, and manuscript elaboration. 
Acknowledgements. We thank all the staff personnel of the Teleprocess Unit at the HHT, for their invaluable contributions to this work.

\section{References}

1. Instituto Nacional de Estadísticas (INE). Instituto Nacional de Estadísticas (INE). [Internet]. 2021 [cited 2021 Apr 8]. Availablefrom: https://www.ine.cl/

2. Gobierno de Chile. Gob.cl - Cifras Oficiales [Internet]. 2021 [cited 2021 Apr 8]. Available from:

https://www.gob.cl/coronavirus/cifrasoficiales/\#resumen

3. Coronavirus Resource Center. COVID-19 Map - Johns Hopkins Coronavirus Resource Center [Internet]. 2021 [cited 2021 Apr 8]. Available from: https://coronavirus.jhu.edu/map.html

4. Wang WW. Updated understanding of the outbreak of 2019 novel coronavirus (2019-nCoV) in Wuhan, China. J Med Virol. 2021 Apr 1;92(4):441-7.

5. Gobierno de Chile. Gob.cl - Cifras Oficiales [Internet]. 2021 [cited 2021 Apr 10]. Available from: https://www.gob.cl/coronavirus/cifrasoficiales/

6. Ministerio de Salud G de C. 4to informe trimestral de garantías de oportunidad respecto a los retrasos en regimen GES. [Internet]. 2019 [cited 2021 Apr 10]. Available from: https://www.minsal.cl/wp-content/uploads/2020/05/Ord-251-Glosa-06.pdf

7. Ministerio de Salud. Glosa 06, Lista de Espera No GES y Garantías de oportunidad GES retrasadas [Internet]. Santiago; 2021 Apr [cited 2021 Jun 30 ]. Available from: https://www.minsal.cl/wp-content/uploads/2021/05/ORD-1204-DIGERA-Glosa-06.pdf

8. Constanzo F, Aracena-Sherck P, Hidalgo JP, Peña L, Marrugo M, Gonzalez J, et al. Contribution of a synchronic teleneurology program to decrease the patient number waiting for a first consultation and their waiting time in Chile. BMC Med Inform DecisMak. 2020 Feb 5;20(1).

9. CENS. Telemedicina durante la epidemia de COVID-19 en Chile: Guía de Buenas Prácticas y Recomendaciones. 2020.

10. Constanzo F, Aracena-Sherck P, Hidalgo JP, Muñoz M, Vergara G, Alvarado C. Validation of a patient satisfaction survey of the Teleneurology program in Chile. BMC Res Notes. 2019;12(1).

11. Constanzo F, Aracena-Sherck P, Hidalgo JP, Peña L, Marrugo M, Gonzalez J, et al. Contribution of a synchronic teleneurology program to decrease the patient number waiting for a first consultation and their waiting time in Chile. BMC Med Inform DecisMak. 2020;20(1).

12. Constanzo FM, Aracena-Sherck P, Peña L, Marrugo M, Gonzalez J, Vergara G, et al. Characterization of the Teleneurology patients at the Hospital Las Higueras de Talcahuano-Chile. Front Neurol. 2020;11:1438.

13. Klein BCNAB. Author response: COVID-19 is catalyzing the adoption of teleneurology | Neurology [Internet]. Neurology. 2020 [cited 2020 May 20 ]. Available from: https://n.neurology.org/content/author-response-covid-19-catalyzing-adoption-teleneurology

14. Camila Meza Sparza. Teleconsultas: la tecnología a favor del paciente en tiempos de pandemia - Universidad Católica de la Santísima Concepción. Noticias UCSC [Internet]. 2020 [cited 2020 May 20]; Available from: https://www.ucsc.cl/noticias/teleconsultas-la-tecnologia-a-favor-del-paciente-entiempos-de-pandemia/

15. Judd E. Hollander MD. and BGCMD. Virtually Perfect? Telemedicine for Covid-19. N Engl J Med. 2020 Apr 30;382:1679-81.

16. Roy B, Nowak RJ, Roda R, Khokhar B, Patwa HS, Lloyd T, et al. Teleneurology during the COVID-19 pandemic: A step forward in modernizing medical care. J Neurol Sci. 2020 Jul 15;414.

17. Craig J, Russell C, Patterson V, Wootton R. User satisfaction with realtime teleneurology. J Telemed Telecare [Internet]. 1999 Dec 23 [cited 2018 Dec 20];5(4):237-41. Available from: http://journals.sagepub.com/doi/10.1258/1357633991933774

18. Ford JA, Pereira A. Does teledermatology reduces secondary care referrals and is it acceptable to patients and doctors?: A service evaluation. J Eval Clin Pract. 2015 Aug 1;21(4):710-6.

19. Dorsey ER, Glidden AM, Holloway MR, Birbeck GL, Schwamm LH. Teleneurology and mobile technologies: the future of neurological care. Nat Rev Neurol [Internet]. 2018 May 6 [cited 2018 Dec 20];14(5):285-97. Available from: http://www.nature.com/doifinder/10.1038/nrneurol.2018.31

20. Mair F, Whitten P. Systematic review of studies of patient satisfaction with telemedicine. BMJ [Internet]. 2000 Jun 3 [cited 2018 Dec 20];320(7248):1517-20. Available from: http://www.ncbi.nlm.nih.gov/pubmed/10834899

21. Powell RE, Henstenburg JM, Cooper G, Hollander JE, Rising KL. Patient Perceptions of Telehealth Primary Care Video Visits. Ann Fam Med [Internet]. 2017 May 8 [cited 2019 Mar 7];15(3):225-9. Available from: http://www.ncbi.nlm.nih.gov/pubmed/28483887

22. Reed ME, Parikh R, Huang J, Ballard DW, Barr I, Wargon C. Real-Time Patient-Provider Video Telemedicine Integrated with Clinical Care. N Engl J Med [Internet]. 2018 Oct 11 [cited 2019 Mar 7];379(15):1478-9. Available from: http://www.nejm.org/doi/10.1056/NEJMc1805746

23. Channer D. Telemedicine Technology. In: Teleneurology in Practice [Internet]. New York, NY: Springer New York; 2015 [cited 2019 Jan 17$]$. p. $39-46$. Available from: http://link.springer.com/10.1007/978-1-4939-2349-6_4

24. Tsao JW, Demaerschalk BM, editors. Teleneurology in Practice [Internet]. New York, NY: Springer New York; 2015 [cited 2019 Jan 17]. Available from: http://link.springer.com/10.1007/978-1-4939-2349-6

25. Weinstein RS, Lian F, Bhattacharyya AK. Teleneuropathology. In: Teleneurology in Practice [Internet]. New York, NY: Springer New York; 2015 [cited 2019 Jan 17]. p. 113-29. Available from: http://link.springer.com/10.1007/978-1-4939-2349-6_11

26. Alexandre de la Court. Principio de suficiencia y prestaciones mínimas de Seguridad Social: una revisión desde el derecho al mínimo de existencia alemán. Rev Derecho. 2019;32(2):165-84.

27. Bakken S, Holzemer WL, Brown M-A, Powell-Cope GM, Turner JG, Inouye J, et al. Relationships Between Perception of Engagement with Health Care Provider and Demographic Characteristics, Health Status, and Adherence to Therapeutic Regimen in Persons with HIV/AIDS. AIDS Patient Care STDS [Internet]. 2000 Apr [cited 2017 Jul 5];14(4):189-97. Available from: http://www.ncbi.nlm.nih.gov/pubmed/10806637

Page 11/13 
28. Dick PT, Filler R, Pavan A. Participant satisfaction and comfort with multidisciplinary pediatric telemedicine consultations. J Pediatr Surg [Internet]. 1999 Jan [cited 2018 Dec 20];34(1):137-41; discussion 141-2. Available from: http://www.ncbi.nlm.nih.gov/pubmed/10022159

29. Demiris G, Speedie SM, Hicks LL. Assessment of Patients' Acceptance of and Satisfaction with Teledermatology. J Med Syst [Internet]. 2004 Dec [cited 2017 Jul 5];28(6):575-9. Available from: http://link.springer.com/10.1023/B:JOMS.0000044959.71456.df

30. Demiris G, Speedie SM, Finkelstein S. Change of Patients' Perceptions of TeleHomeCare. Telemed J e-Health [Internet]. 2001 Sep [cited 2017 Jul 5];7(3):241-8. Available from: http://www.ncbi.nlm.nih.gov/pubmed/11564360

31. Demiris G, Speedie S, Finkelstein S. A questionnaire for the assessment of patients' impressions of the risks and benefits of home telecare. J Telemed Telecare [Internet]. 2000 Oct [cited 2017 Jul 5];6(5):278-84. Available from: http://www.ncbi.nlm.nih.gov/pubmed/11070589

32. Bakken S, Grullon-Figueroa L, Izquierdo R, Lee N-J, Morin P, Palmas W, et al. Development, Validation, and Use of English and Spanish Versions of the Telemedicine Satisfaction and Usefulness Questionnaire. J Am Med Informatics Assoc [Internet]. 2006 Nov 1 [cited 2017 Jul 5];13(6):660-7. Available from: http://www.ncbi.nlm.nih.gov/pubmed/16929036

33. Telemedicine Forms - The Source [Internet]. [cited $2017 \mathrm{Jul}$ 5]. Available from: http://hub.americantelemed.org/thesource/resources/telemedicineforms

\section{Figures}

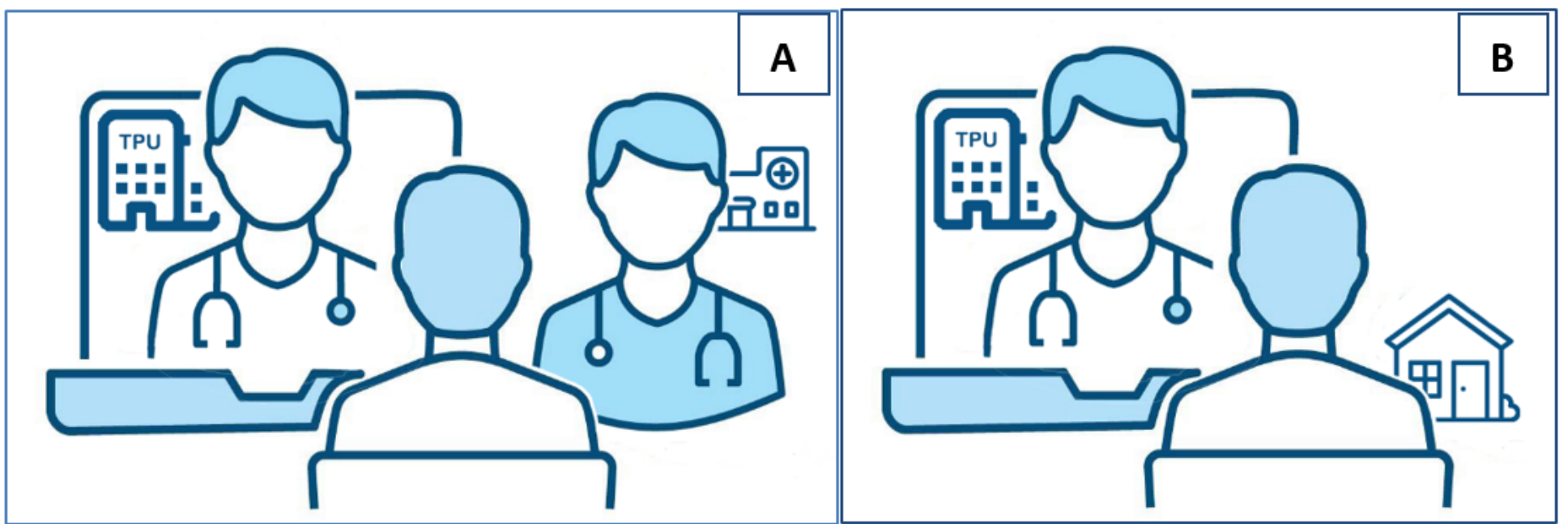

Figure 1

Representation of the assisted televisit (A) and televisit (B) used before and during COVI-19 pandemic, provided by Teleprocess Unit (TPU). ORIGINAL PICTURE.

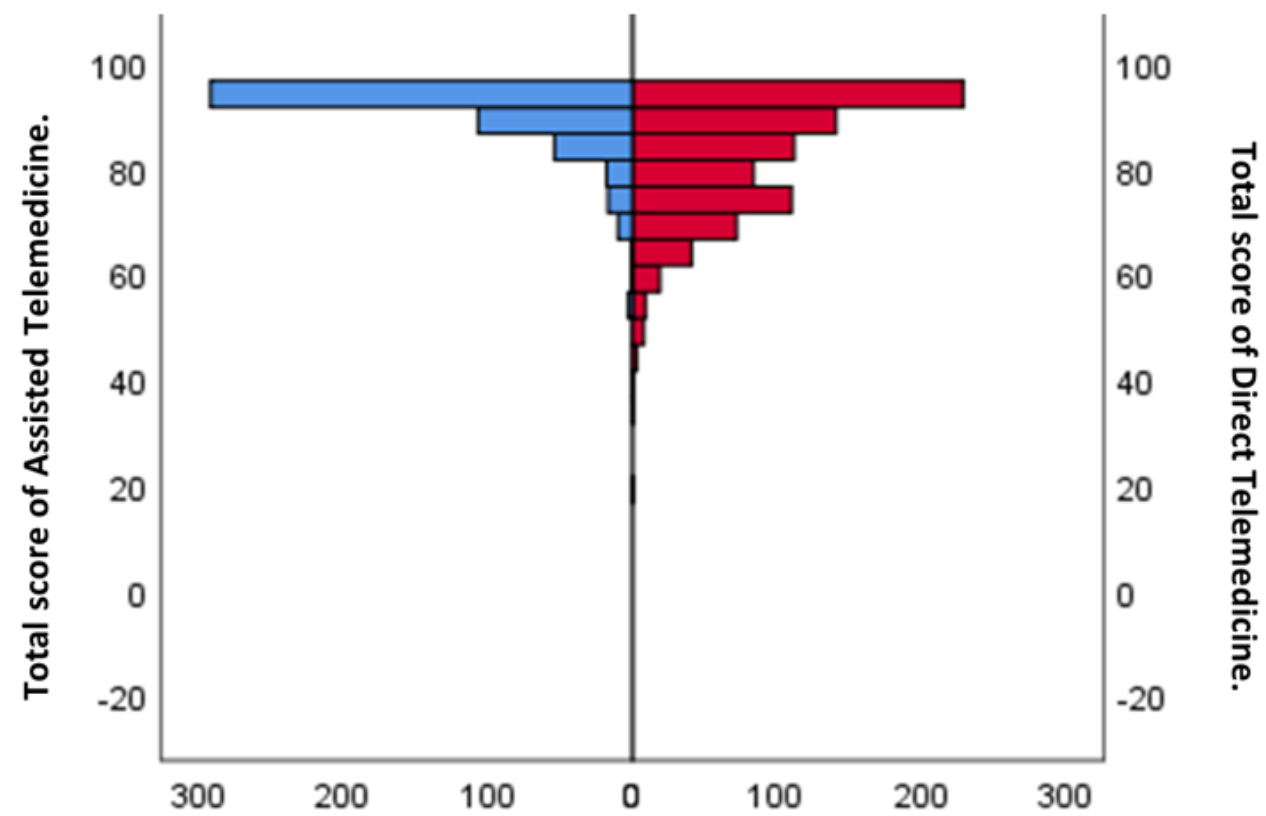


Figure 2

We compare the user satisfaction between assisted televisit (left-blue, $\mathrm{N}=503$ ) and televisit (right-red, $\mathrm{N}=831$ ). The Mann-Whitley $\mathrm{U}$ test for independent samples showed a significant difference between the two populations distribution $(p=0.000)$. ORIGINAL PICTURE.

\section{Supplementary Files}

This is a list of supplementary files associated with this preprint. Click to download.

- DATABASE2021.xIsx 